\title{
The influence of high temperature on the possibility of DNA typing in various human tissues
}

\author{
Agnieszka Maciejewska' ${ }^{1}$, Renata Wlodarczyk ${ }^{2}$, Ryszard Pawlowski ${ }^{1}$ \\ ${ }^{1}$ Institute of Forensic Medicine, Medical University of Gdansk, Gdansk, Poland \\ ${ }^{2}$ Police Academy in Szczytno, Szczytno, Poland
}

\begin{abstract}
Introduction. The identification of unknown victims of high temperatures (fire, terrorist attack, and other disasters) is one of the most difficult tasks faced by forensic geneticists. The main aim of this study was to investigate the availability of DNA isolated from various human tissue samples exposed to high temperatures of $100-1000^{\circ} \mathrm{C}$ for 5 and 10 minutes.

Material and methods. Samples of varying thickness of thigh muscle, liver, heart, adipose tissue, bone, teeth, hair and nails of 52 fresh cadavers and 59 healthy teeth of 29 volunteers were used. The study was performed using the following commercially available STR (Short Tandem Repeats) and miniSTR kits: AmpFISTR ${ }^{\circledR}$ SGM Plus $^{\circledR}$ and AmpFISTR ${ }^{\circledR}$ MiniFiler ${ }^{\mathrm{TM}}$. Hyper variable region I (HVI) of human mitochondrial DNA (mtDNA) was sequenced with BigDye Terminator Cycle Sequencing Kit 1.1. The PEP (Primer-Extension Preamplification) method was used for the whole human genome amplification.

Results. It was possible to obtain complete DNA profiles (AmpFISTR ${ }^{\circledR}$ SGM Plus ${ }^{\circledR}$, AmpFISTR ${ }^{\circledR}$ MiniFiler ${ }^{\mathrm{TM}}$ Applied Biosystems, USA and mtDNA HVI region) for tissue samples of heart, liver and thigh muscle, exposed up to $900^{\circ} \mathrm{C}$ for $5 \mathrm{~min}$. However, under the applied conditions, limited usefulness of hair, nails and teeth for identification purposes was shown.

Conclusions. DNA stability in tissues subjected to incineration depends on many factors, like tissue type and its thickness, temperature and time of exposure. In the cases of human remains exposed to high temperatures, samples of soft tissues of the highest weight (thickness) provide the best chance of successful identification through the genetic analysis.

In some cases of negative results, even if using mtDNA typing, application of the whole genome amplification (WGA) technique could provide the expected results for highly degraded DNA templates. (Folia Histochemica et Cytobiologica 2015, Vol. 53, No. 4, 322-332)
\end{abstract}

Key words: human tissues; DNA identification; DNA stability; high temperatures; STR; mtDNA; WGA

\section{Introduction}

In a number of crimes and accidents including fires, plane crashes, traffic accidents or terrorist attacks, the degradation of biological material by the effect of high temperatures must be addressed [1-3]. A remarkable example is the attack on the World Trade

Correspondence address: Prof. R. Pawlowski, M.D., Ph.D. Institute of Forensic Medicine Medical University of Gdansk

Debowa 23, 80-204 Gdansk

tel.: +48 5834917 44, fax: +48583491253

e-mail: richard@gumed.edu.pl
Center towers in 2001 and the problems with victim identification, which were largely associated with high temperatures (approx. $1100^{\circ} \mathrm{C}$ at Ground Zero) [4-6]. As a result of the high temperature exposure, the DNA available for analysis is highly thermally degraded and frequently present in very few copies. A trace amount of template DNA available for amplification very frequently leads to different types of artifacts such as a lack of amplification of particular alleles (allele drop-out) or loci (loci drop-out) [7-10]. The problem of the effect of high temperature on biological material and the possibility of DNA identification has been rarely mentioned. It is well known that biological and/or physical DNA degradation 
depends on many factors like temperature, humidity, UV penetration, type of soil etc. [11, 12]. The degree of degradation also depends on the type of analyzed tissue. In the cases of severely degraded human tissues full DNA profiles are obtained more effectively from hard tissues than from soft ones since DNA from bones is usually less degraded than that from blood or soft tissues [3]. Additionally, in case of hard tissues typing success rate depends on type of human bones used for identification purposes [13]. DNA yield and stability in different soft human tissues vary substantially [14] and are highly dependent on physical and chemical factors. In many cases reduction of amplicon size, like substituting STR (Short Tandem Repeats) with miniSTR loci or SNPs, can drastically improve DNA typing results $[9,11,12,15]$.

Success of DNA profiling process depends also on the number of DNA copies available to PCR amplification. Usually, when DNA template is drastically degraded and nuclear DNA typing gives negative results, mitochondrial DNA (mtDNA) typing gives satisfactory results [16-18]. Since only few authors have studied the effects of high temperatures on the success of DNA identification, we decided to systematically investigate the availability of DNA isolated from various human tissue samples exposed to high temperatures of $100-1000^{\circ} \mathrm{C}$ for 5 and 10 minutes.

\section{Material and methods}

In our experiments DNA isolated from various human tissues of different thicknesses exposed for 5 or $10 \mathrm{~min}$ to temperatures in the range from $100^{\circ} \mathrm{C}$ to $1000^{\circ} \mathrm{C}$ was profiled using two tactics. The first tactic was based on the analysis of STR (Short Tandem Repeats) and miniSTR loci amplification and, in the case of a negative outcome, mtDNA sequencing was performed. The study was performed using the commercially available STR and miniSTR kits: AmpFISTR ${ }^{\circledR}$ SGM Plus ${ }^{\circledR}$ and AmpFISTR ${ }^{\circledR}$ MiniFiler $^{\mathrm{TM}}$ [7, 19-22]. Amplification of hyper variable region I (HVI) of human mitochondrial DNA (mtDNA) was used [2, 4, 23] when STR and miniSTR typings gave negative results. The second tactic used whole genome amplification (WGA) as a method of multiplying the amount of the matrix prior to the amplification of polymorphic DNA loci [24-28]. WGA technique was applied for bones burned in $900^{\circ} \mathrm{C}$ for $5 \mathrm{~min}$, which had not given positive results of nuclear and mitochondrial DNA amplification.

Source of reference DNA. Peripheral blood collected from 52 fresh cadavers (up to 32 hours post mortem) was used as the reference material for all analyzed soft tissue fragments and fibula. Buccal swabs collected from healthy donors were used as the reference material for teeth.
Preparation of biological material collected from cadavers. The following tissues were selected for the study: thigh skeletal muscle, liver, cardiac muscle (front wall), adipose tissue from the abwith fragments of the skin (abdomen), extracted hair (head, occiput), nails (leg), and long bone (fibula). The material was collected from 52 cadavers, with the exception of the long bones, which were collected from 30 cadavers. The study was approved by the Ethics Committee of the Medical University of Gdansk (No. NKEBN/477/2007) and the Ethics Committee of Pomeranian Medical University (PUM BN-001/255/02).

All samples were prepared using sterile, disposable scalpels, blades and scissors, which were washed with sodium hypochlorite and sterile water and subjected to UV radiation (Crosslinker 254 nm Herolab, Herolab GmbH Laborgeräte, Wiesloch, Germany) for 30 minutes.

All bones and teeth were decontaminated as described by Jakubowska et al. [29]. Nails were washed with sterile water $\left(15 \mathrm{~min}, 500^{\circ} \mathrm{C}\right.$, under shaking conditions) which was followed by absolute ethanol washing for 3 min [30]. Hairs were decontaminated according to Jehaes et al. [31].

All tissues were wrapped in disposable, sterile and resistant to high temperature $\left(1000^{\circ} \mathrm{C}\right)$ aluminum foil which was subjected to UV radiation for $30 \mathrm{~min}$ to avoid samples spattering. Samples wrapped in foil were placed in the furnace heated to given temperature.

Preparation of healthy teeth collected from volunteers. In total, 56 healthy teeth, including 21 premolars and 35 molars bearing no signs of dental treatment, were collected appropriately from 29 patients in a dental practice. After collection, the teeth were stored at $-20^{\circ} \mathrm{C}$ until exposure to the high temperature.

Exposure of the biological material to high temperature. Fragments of thigh skeletal muscle, liver, heart (thickness: $2 \mathrm{~cm}$ and $0.5 \mathrm{~cm}$ ), adipose tissue with hypodermis fragments (thickness: $2 \mathrm{~cm}$ ), fibula fragments (thickness: $2 \mathrm{~cm}$ ), teeth (thickness: ca. $0.5 \mathrm{~cm}$ ), were subjected to incineration in a laboratory furnace (ZALMED PL-11/1100, ZALMED, Lomianki, Poland) with the regulated temperatures of $100^{\circ} \mathrm{C}, 300^{\circ} \mathrm{C}, 500^{\circ} \mathrm{C}, 700^{\circ} \mathrm{C}, 800^{\circ} \mathrm{C}, 900^{\circ} \mathrm{C}$ and $1000^{\circ} \mathrm{C}$ for 5 or $10 \mathrm{~min}$.

Hair containing hair bulb and nails (from leg) were subjected to incineration in a laboratory furnace at $100^{\circ} \mathrm{C}$, $300^{\circ} \mathrm{C}, 500^{\circ} \mathrm{C}, 700^{\circ} \mathrm{C}$ or $800^{\circ} \mathrm{C}$ for 5 minutes.

DNA isolation and quantification. The teeth and fibula fragments were ground in a bone mill in liquid nitrogen (6850FreezMill,SpexCertiPrep, Metuchen, New Jersey,USA). DNA was isolated from the peripheral blood and incinerated biological material using the phenol-chloroform method with proteinase $\mathrm{K}$ treatment [32]. DNA was purified twice 
and concentrated on Microcon 100 columns (Merck Millipore Ltd, Tullagreen, Carrigtwohill Co. Cork, IRL). DNA quantification was performed by Real-Time PCR using a 7900HT Fast RealTime PCR System (Applied Biosystems, Foster City, CA, USA) with a Quantifiler ${ }^{\mathrm{TM}}$ kit (Applied Biosystems), according to the manufacturer's protocol, and PicoGreen ${ }^{\mathrm{TM}}$ (Fluoroskan Ascent, ThermoLabsystem, Helsinki, Finland).

Amplification of the whole human genome using WGA technique. The PEP (Primer-Extension Preamplification) method was used for the whole human genome amplification [26]. The method was validated and modified in our laboratory [27] and used to amplify thermally degraded DNA. It was applied for two fibula fragments incinerated at $900^{\circ} \mathrm{C}$ for $5 \mathrm{~min}$.

Analysis of DNA loci. The isolated DNA was subjected to amplification using commercial multiplex PCR kits AmpFISTR $^{\circledR}$ SGM Plus ${ }^{\circledR}$ (allele size range: 100 bp-350 bp) and AmpFlSTR ${ }^{\circledR}$ MiniFiler $^{\mathrm{TM}}$ (allele size range: 75 bp-280 bp) (both Applied Biosystems) [20-21]. The HVI region of mtDNA was sequenced using the HVI F15971 R16410 primers and the BigDye Terminator Cycle Sequencing Kit 1.1 (Applied Biosystems). The reactions were performed according to the manufacturer's manuals. If possible, $1 \mathrm{ng}$ of DNA was added; otherwise, a lower amount of DNA was added (particularly extracted from the teeth). SGMPlus and MiniFiler products were separated and analyzed using ABI Prism 3130 (Applied Biosystems), and mtDNA was sequenced using an ABI Prism 310 (Applied Biosystems). For MiniFiler and SGMPlus profiles, the threshold value for the analysis was established at the $100 \mathrm{RFU}$ (relative fluorescence unit) level.

Ways of identification analyzed samples with reference DNA. The autosomal loci (SGMPlus and MiniFiler) and the mtDNA HVI region of the experimental and reference samples were analyzed. The profiles were subjected to detailed analysis as follows: the concordance with the reference sample profiles and, in particular, the completeness of the profiles (allele drop-outs and locus drop-outs), the heterozygote balance and the presence of additional amplicons (drop-ins) in a size range of the analyzed loci were investigated. The presence of all the alleles consistent with those observed in the reference material was evaluated as $100 \%$, and the complete lack of amplification as $0 \%$. The significant difference of the heterozygote alleles was set to the height of one of the alleles of less than $60 \%$ [33]. For the mtDNA, the legible, correct sequence obtained for all the tested samples was determined as $(+)$, and the complete lack of amplification as (-).

\section{Results}

\section{The percentage of amplified SGMPlus and \\ MiniFiler alleles and the result of $\mathrm{mtDNA}$ profiling obtained for different tissues}

Tables 1 and 2 show the percentage of the amplified alleles (SGMPlus, MiniFiler) and the results of the mtDNA profiling obtained for all the analyzed tissues incinerated at different temperatures for 5 or 10 minutes.

\section{The thermal stability of DNA in hair and nails}

No amplification of any of the tested loci of the SGMPlus, MiniFiler or mtDNA sequences was obtained for the samples of hair and nails subjected to temperatures ranging from $100^{\circ} \mathrm{C}$ to $800^{\circ} \mathrm{C}$ (Table 1 ). A negative result for the hair samples was expected because $100^{\circ} \mathrm{C}$ treatment led to their complete incineration. The negative amplification results were also observed for nails (Table 1).

\section{The effects of high temperatures on teeth DNA profiling}

Complete DNA profiles that were consistent with the reference material and artifact-free were obtained for healthy, nonrestored teeth for all the tested markers (SGMPlus, MiniFiler and mtDNA HVI) only after exposure to $100^{\circ} \mathrm{C}$ for 5 and $10 \mathrm{~min}$ (Tables 1 and 2). In the SGMPlus system, the teeth exposed to $300^{\circ} \mathrm{C}$ for 5 and $10 \mathrm{~min}$ gave a positive signal for $63 \%$ and $31 \%$ of alleles, respectively, with allele and locus drop-outs. Particularly long amplicons such as FGA, D16S539, D2S1338 and D18S51 were lost (Figure 1). There were no other artifacts in the analyzed profiles. However, all the loci were properly identified after the identical treatment, when using MiniFiler method, which analyzes the amplicons of shorter length than SGMPlus and thus gives a better probability of obtaining a signal for more degraded matrices. Figure 2 shows the MiniFiler profiles obtained for the teeth subjected to $300^{\circ} \mathrm{C}$ and $500^{\circ} \mathrm{C}$ for $5 \mathrm{~min}$. Increasing the temperature to $500^{\circ} \mathrm{C}$ and higher resulted in a complete inability of the SGMPlus and MiniFiler profile determination (Table 1).

In an attempt to increase the amount of the DNA template, two teeth from the same person, instead of one, were subjected to the temperature of $500^{\circ} \mathrm{C}$. However, no positive effect for the SGMPlus and MiniFiler systems was obtained (data not shown).

Complete sequences of HVI mtDNA, identical with the reference sequences, were obtained only for teeth samples exposed to $100^{\circ} \mathrm{C}, 300^{\circ} \mathrm{C}$ and $500^{\circ} \mathrm{C}$ for 5 min (Supplementary Figure 1). 
Table 1. The percentage of amplified SGMPlus and MiniFiler alleles and the result of mtDNA profiling obtained for different tissues exposed to temperature in the $100-1000^{\circ} \mathrm{C}$ range for 5 minutes

\begin{tabular}{|c|c|c|c|c|c|c|c|c|c|c|c|c|c|c|c|c|c|c|c|c|c|}
\hline \multirow[b]{3}{*}{ Tissue type } & \multicolumn{21}{|c|}{ Temperature of tissues' combustion for 5 minutes } \\
\hline & \multicolumn{3}{|c|}{$100^{\circ} \mathrm{C}$} & \multicolumn{3}{|c|}{$300^{\circ} \mathrm{C}$} & \multicolumn{3}{|c|}{$500^{\circ} \mathbf{C}$} & \multicolumn{3}{|c|}{$700^{\circ} \mathrm{C}$} & \multicolumn{3}{|c|}{$800^{\circ} \mathrm{C}$} & \multicolumn{3}{|c|}{$900^{\circ} \mathrm{C}$} & \multicolumn{3}{|c|}{$1000^{\circ} \mathrm{C}$} \\
\hline & 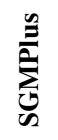 & 离 & $\sum$ & 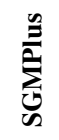 & 离 & $\sum$ & 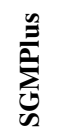 & 离 & $\sum$ & $\sum_{\substack{0\\
}}^{\infty}$ & 离 & $\sum$ & 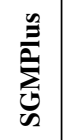 & 离 & $\sum$ & 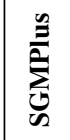 & 离 & $\sum$ & 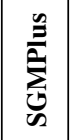 & 离 & $\sum$ \\
\hline \multirow{2}{*}{$\begin{array}{l}\text { Thigh muscle } \\
\left(2 \mathrm{~cm}^{\&}\right) \\
\text { Thigh muscle } \\
\left(0.5 \mathrm{~cm}^{\&}\right)\end{array}$} & 100 & 100 & + & 100 & 100 & + & 100 & 100 & + & 100 & 100 & + & 100 & 100 & + & 100 & 100 & + & 0 & 0 & - \\
\hline & 100 & 100 & + & 100 & 100 & + & 100 & 100 & + & 66 & 100 & + & 52 & 100 & + & 0 & 0 & - & 0 & 0 & - \\
\hline \multirow{2}{*}{$\begin{array}{l}\text { Liver }\left(2 \mathrm{~cm}^{\star}\right) \\
\text { Liver }\left(0.5 \mathrm{~cm}^{\&}\right)\end{array}$} & 100 & 100 & + & 100 & 100 & + & 100 & 100 & + & 100 & 100 & + & 100 & 100 & + & 100 & 100 & + & 0 & 0 & - \\
\hline & 100 & 100 & + & 100 & 100 & + & 100 & 100 & + & 63 & 100 & + & 45 & 100 & + & 0 & 0 & - & 0 & 0 & - \\
\hline \multirow{2}{*}{$\begin{array}{l}\text { Cardiac muscle } \\
\left(2 \mathrm{~cm}^{\&}\right) \\
\text { Cardiac muscle } \\
\left(0.5 \mathrm{~cm}^{\&}\right)\end{array}$} & 100 & 100 & + & 100 & 100 & + & 100 & 100 & + & 100 & 100 & + & 100 & 100 & + & 100 & 100 & + & 0 & 0 & - \\
\hline & 100 & 100 & + & 100 & 100 & + & 100 & 100 & + & 72 & 100 & + & 57 & 100 & + & 0 & 0 & - & 0 & 0 & - \\
\hline $\begin{array}{l}\text { Adipose tissue } \\
\left(2 \mathrm{~cm}^{\&}\right)\end{array}$ & 100 & 100 & + & 100 & 100 & + & 100 & 100 & + & 0 & 0 & - & 0 & 0 & - & 0 & 0 & - & 0 & 0 & - \\
\hline $\begin{array}{l}\text { Fibula fragment } \\
\left(2 \mathrm{~cm}^{\&}\right)\end{array}$ & 100 & 100 & + & 100 & 100 & + & 100 & 100 & + & 100 & 100 & + & 100 & 100 & + & $\begin{array}{l}\mathrm{AG} \\
(33 \%)\end{array}$ & $\begin{array}{c}\mathrm{AG} \\
(33 \%)\end{array}$ & $\mid \begin{array}{c}+ \\
(4 / 6)^{*}\end{array}$ & 0 & 0 & - \\
\hline $\begin{array}{l}\text { Healthy teeth } \\
\left(0.5 \mathrm{~cm}^{\&}\right)\end{array}$ & 100 & 100 & + & 63 & 100 & + & 0 & 0 & $+*$ & 0 & 0 & - & 0 & 0 & - & 0 & 0 & - & 0 & 0 & - \\
\hline Hair & 0 & 0 & 0 & 0 & 0 & 0 & 0 & 0 & 0 & 0 & 0 & 0 & 0 & 0 & 0 & n.a. & n.a. & n.a. & n.a. & n.a. & n.a. \\
\hline Nails fragments & 0 & 0 & 0 & 0 & 0 & 0 & 0 & 0 & 0 & 0 & 0 & 0 & 0 & 0 & 0 & n.a. & n.a. & n.a. & n.a. & n.a. & n.a. \\
\hline
\end{tabular}

Comparison analysis was performed as described in Material and methods. For the mtDNA, the legible, correct sequence obtained for all the tested samples was determined as (+), and the complete lack of amplification as (-). Values represent percentage of alleles consistent with those observed in the reference material, full profile was evaluated as $100 \%$, and the complete lack of amplification as $0 \%$. \&thickness of tissue fragment; $(+)$ - HVI mtDNA sequence was successfully amplified; $(-)$ - HVI mtDNA sequence amplification failure; n.a. — was not analyzed; ${ }^{\text {the }}$ result was positive for 4 of 6 analyzed bones. 2 bones that gave negative result were preamplified with PEP (Primer-Extension Preamplification) method, what gave a positive result in 1 of 2 analyzed cases; *the result was positive for one of two molar teeth; AG - amelogenin, an amplification signal was obtained only for the amelogenin locus (in brackets the percentage of amelogenin positive samples)

At higher temperatures $\left(700-1000^{\circ} \mathrm{C}\right)$, teeth underwent partial or total incineration, which led to failure of mtDNA amplification.

Among tooth samples subjected to combustion for 10 minutes, complete profiles were obtained with SGMPlus kit after $100^{\circ} \mathrm{C}$, and with MiniFiler after $100^{\circ} \mathrm{C}$ and $300^{\circ} \mathrm{C}$ exposure (Supplementary Figures 2 and 3 ).

We showed (Table 1) that the exposure of teeth to $300^{\circ} \mathrm{C}$ for $5 \mathrm{~min}$ provides full MiniFiler and mtDNA profiles and a partial SGMPlus profile (63\%), whereas exposure to $300^{\circ} \mathrm{C}$ for 10 min yields a full profile for MiniFiler and mtDNA and a partial profile (31\%) for SGMPlus.

\section{The effects of high temperatures on bone DNA}

The fibula fragments were subjected to combustion at temperatures from $100^{\circ} \mathrm{C}$ to $1000^{\circ} \mathrm{C}$ for $5 \mathrm{~min}$ (Table 1). After $100^{\circ} \mathrm{C}, 300^{\circ} \mathrm{C}, 500^{\circ} \mathrm{C}, 700^{\circ} \mathrm{C}$ and $800^{\circ} \mathrm{C}$ exposure, all the MiniFiler and SGMPlus loci were identified (Supplementary Figure 4). The obtained DNA profiles did not show the allele and locus dropouts and were consistent with the reference material.

Burning the fibula fragments obtained from 6 subjects at $900^{\circ} \mathrm{C}$ for $5 \mathrm{~min}$ resulted in almost complete degradation of nuclear DNA. The amelogenin locus underwent amplification, however, only in 2 of 6 bone samples (for each bone SGM Plus and MiniFiler results were consistent) (Table 1). Therefore, mtDNA stability was tested. In 4 of 6 tested samples (two amelogenin locus positive and two amelogenin locus negative), a reliable HVI sequence was obtained (Supplementary Figure 5).

For the remaining two samples, the mtDNA sequence was not obtained, therefore the PEP method [27] was applied, and then the HVI mtDNA region was analyzed. For one of the two samples, the complete and reliable HVI mtDNA sequence was obtained, which was identical with the reference 
Table 2. The percentage of amplified SGMPlus and MiniFiler alleles and the result of the mtDNA profiling obtained for various tissues exposed to temperature in the $100-1000^{\circ} \mathrm{C}$ range for 10 minutes

\begin{tabular}{|c|c|c|c|c|c|c|c|c|c|c|c|c|c|c|c|c|c|c|c|c|c|}
\hline \multirow[b]{3}{*}{ Tissue type } & \multicolumn{21}{|c|}{ Temperature of tissues' combustion for 10 minutes } \\
\hline & \multicolumn{3}{|c|}{$100^{\circ} \mathrm{C}$} & \multicolumn{3}{|c|}{$300^{\circ} \mathrm{C}$} & \multicolumn{3}{|c|}{$500^{\circ} \mathrm{C}$} & \multicolumn{3}{|c|}{$700^{\circ} \mathrm{C}$} & \multicolumn{3}{|c|}{$800^{\circ} \mathrm{C}$} & \multicolumn{3}{|c|}{$900^{\circ} \mathrm{C}$} & \multicolumn{3}{|c|}{$1000^{\circ} \mathrm{C}$} \\
\hline & 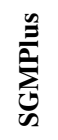 & 离 & $\sum$ & 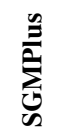 & 离 & $\sum$ & 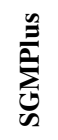 & 离 & $\sum$ & 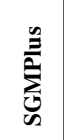 & 离 & $\sum$ & 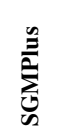 & 氦 & 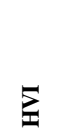 & 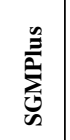 & 离 & $\sum$ & 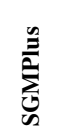 & 离 & $\sum$ \\
\hline \multirow{2}{*}{$\begin{array}{l}\text { Thigh muscle } \\
\left(2 \mathrm{~cm}^{\&}\right) \\
\text { Thigh muscle } \\
\left(0.5 \mathrm{~cm}^{\star}\right)\end{array}$} & 100 & 100 & + & 100 & 100 & + & 100 & 100 & + & 16 & 100 & + & 0 & 0 & - & 0 & 0 & - & 0 & 0 & - \\
\hline & 100 & 100 & + & 100 & 100 & + & 58 & 100 & + & 0 & 0 & - & 0 & 0 & - & 0 & 0 & - & 0 & 0 & - \\
\hline \multirow{2}{*}{$\begin{array}{l}\text { Liver }\left(2 \mathrm{~cm}^{\&}\right) \\
\text { Liver }\left(0.5 \mathrm{~cm}^{\star}\right)\end{array}$} & 100 & 100 & + & 100 & 100 & + & 100 & 100 & + & 10 & 100 & + & 0 & 0 & - & 0 & 0 & - & 0 & 0 & - \\
\hline & 100 & 100 & + & 100 & 100 & + & 52 & 100 & + & 0 & 0 & - & 0 & 0 & - & 0 & 0 & - & 0 & 0 & - \\
\hline \multirow{2}{*}{$\begin{array}{l}\text { Cardiac muscle } \\
\left(2 \mathrm{~cm}^{\&}\right) \\
\text { Cardiac muscle } \\
\left(0.5 \mathrm{~cm}^{\&}\right)\end{array}$} & 100 & 100 & + & 100 & 100 & + & 100 & 100 & + & 21 & 100 & + & 0 & 0 & - & 0 & 0 & - & 0 & 0 & - \\
\hline & 100 & 100 & + & 100 & 100 & + & 58 & 100 & + & 0 & 0 & - & 0 & 0 & - & 0 & 0 & - & 0 & 0 & - \\
\hline $\begin{array}{l}\text { Adipose tissue } \\
\text { with hypodermis } \\
\left(2 \mathrm{~cm}^{\&}\right)\end{array}$ & 100 & 100 & + & 100 & 100 & + & 0 & 0 & - & 0 & 0 & - & 0 & 0 & - & 0 & 0 & - & 0 & 0 & - \\
\hline $\begin{array}{l}\text { Fibula fragment } \\
\left(2 \mathrm{~cm}^{\&}\right)\end{array}$ & n.a. & n.a. & n.a. & n.a. & n.a. & n.a. & n.a. & n.a. & n.a. & n.a. & n.a. & n.a. & n.a. & n.a. & n.a. & 0 & 0 & - & 0 & 0 & - \\
\hline $\begin{array}{l}\text { Healthy teeth } \\
\left(0.5 \mathrm{~cm}^{\&}\right)\end{array}$ & 100 & 100 & + & 31 & 100 & + & 0 & 0 & - & 0 & 0 & - & 0 & 0 & - & 0 & 0 & - & 0 & 0 & - \\
\hline Hair & n.a. & n.a. & n.a. & n.a. & n.a. & n.a. & n.a. & n.a. & n.a. & n.a. & n.a. & n.a. & n.a. & n.a. & n.a. & n.a. & n.a. & n.a. & n.a. & n.a. & n.a. \\
\hline Nails fragments & n.a. & n.a. & n.a. & n.a. & n.a. & n.a. & n.a. & n.a. & n.a. & n.a. & n.a. & n.a. & n.a. & n.a. & n.a. & n.a. & n.a. & n.a. & n.a. & n.a. & n.a. \\
\hline
\end{tabular}

Comparison analysis was performed as described in Material and methods. For the mtDNA, the legible, correct sequence obtained for all the tested samples was determined as $(+)$, and the complete lack of amplification as $(-)$. Values represent percentage of alleles consistent with those observed in the reference material, full profile was evaluated as $100 \%$, and the complete lack of amplification as $0 \%$. \&thickness of tissue fragment; $(+)$ - HVI mtDNA sequence was successfully amplified; (-) — HVI mtDNA sequence amplification failure; n.a. — was not analyzed

sequence. No mtDNA profile was obtained for the second sample subjected to PEP preamplification. According to our previous research, WGA methods, including PEP (Primer-Extension Preamplification) technique, may be useful in some cases in analyzing LCN or degraded DNA in forensic genetics, especially after application of some improvements (sample pooling and replicate DNA typing) [27]. Figure 3 shows the HVI mtDNA profile obtained after PEP preamplification for fibula fragments burned at $900^{\circ} \mathrm{C}$ for 5 min. A similar attempt at DNA reactivation with PEP was undertaken for bones exposed to the highest analyzed temperature of $1000^{\circ} \mathrm{C}$, however, neither of the two analyzed bones yielded a positive result in the mtDNA analysis. Exposure to such a high temperature for up to 5 minutes resulted in an almost complete incineration of the bones, which completely prevented mtDNA determination even after the initial preamplification with PEP.

DNA isolated from fibula fragments exposed to $900^{\circ} \mathrm{C}$ and $1000^{\circ} \mathrm{C}$ for 10 min underwent very strong degradation as well. No amplification was obtained for the tested loci of MiniFiler, SGMPlus and mtDNA (Table 2).

Temperatures above $900^{\circ} \mathrm{C}$ caused incineration of all the tested tissues, and, thus, no positive result was obtained for nuclear DNA and mtDNA (Tables 1 and 2).

\section{The influence of temperature, duration of combustion and thickness of the examined soft tissue fragments on DNA stability}

\section{Combustion of soft tissue for 5 minutes}

Complete and reliable SGMPlus, MiniFiler and mtDNA profiles (heterozygote ratios $\geq 60 \%$ and lack of allele drop-out and loci drop-out and additional peaks) were obtained for thin fragments $(0.5 \mathrm{~cm})$ and adipose tissue with hypodermis fragments exposed to $100-500^{\circ} \mathrm{C}$ for $5 \mathrm{~min}$ (Table 1 ). After the exposure to at higher temperatures $\left(700-1000^{\circ} \mathrm{C}\right)$, the adipose tissue did not yield amplification in any of the tested systems 


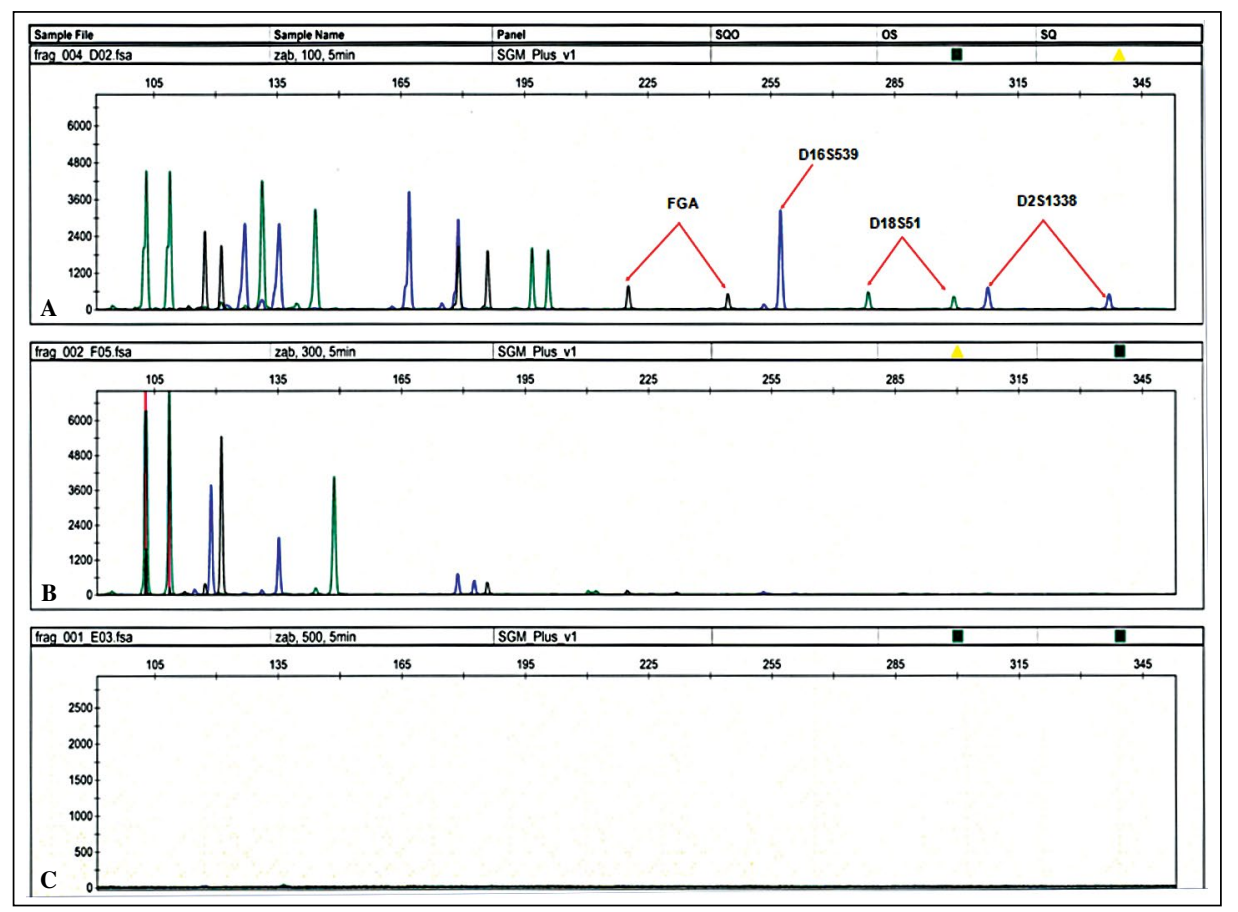

Figure 1. The SGMPlus profiles obtained for the teeth exposed to $100^{\circ} \mathrm{C}(\mathbf{A}), 300^{\circ} \mathrm{C}(\mathbf{B})$ and $500^{\circ} \mathrm{C}(\mathbf{C})$ for 5 min. The profiles were obtained for teeth from different individuals. The arrows indicate loci: FGA, D16S539, D2S1338 and D18S51. $\mathrm{X}$ axis — length of the product (nucleotides); Y axis — relative fluorescence units (RFU)

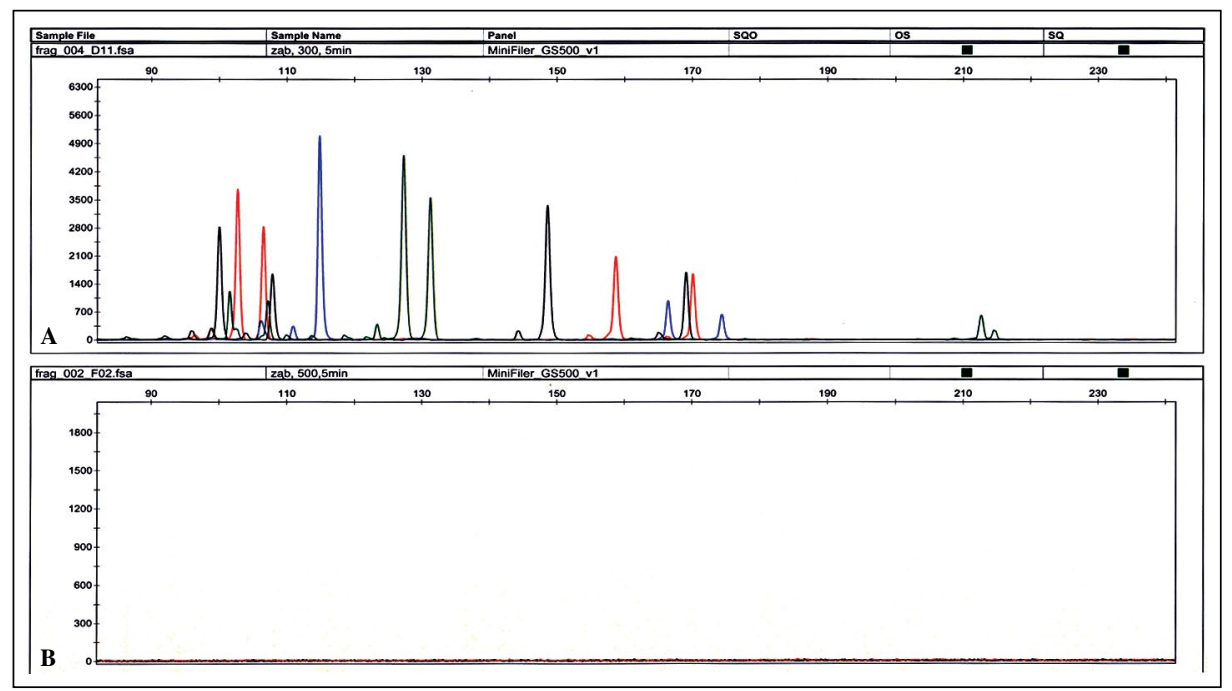

Figure 2. The MiniFiler profiles obtained for teeth exposed to $300^{\circ} \mathrm{C}(\mathbf{A})$ and $500^{\circ} \mathrm{C}(\mathbf{B})$ for 5 min

(SGMPlus, MiniFiler and mtDNA), which indicates its lowest suitability for forensic identification among the analyzed soft tissues (Supplementary Figures 6 and 7).

For other soft tissues, i.e. fragments of heart, liver and thigh muscle tissues, the treatment at $700^{\circ} \mathrm{C}$ and higher temperatures led to the occurrence of incomplete and imbalanced SGMPlus profiles with a heterozygotes ratio below $60 \%$ (Supplementary Figure 8). The fragments $0.5 \mathrm{~cm}$-thick at higher temperatures than $800^{\circ} \mathrm{C}$ yielded no amplification products at all the SGMPlus loci (Table 1). Complete profiles for MiniFiler (Supplementary Figure 9) and mtDNA were obtained for the tissues treated at temperatures from $100^{\circ} \mathrm{C}$ to $800^{\circ} \mathrm{C}$. No signals were obtained for the tissues treated at $900^{\circ} \mathrm{C}$ or $1000^{\circ} \mathrm{C}$ (Table 1).

To examine the effect of the tissue thickness on the possibility of DNA identification, four-fold thicker fragments of soft tissue were analyzed; $2 \mathrm{~cm}$-thick 


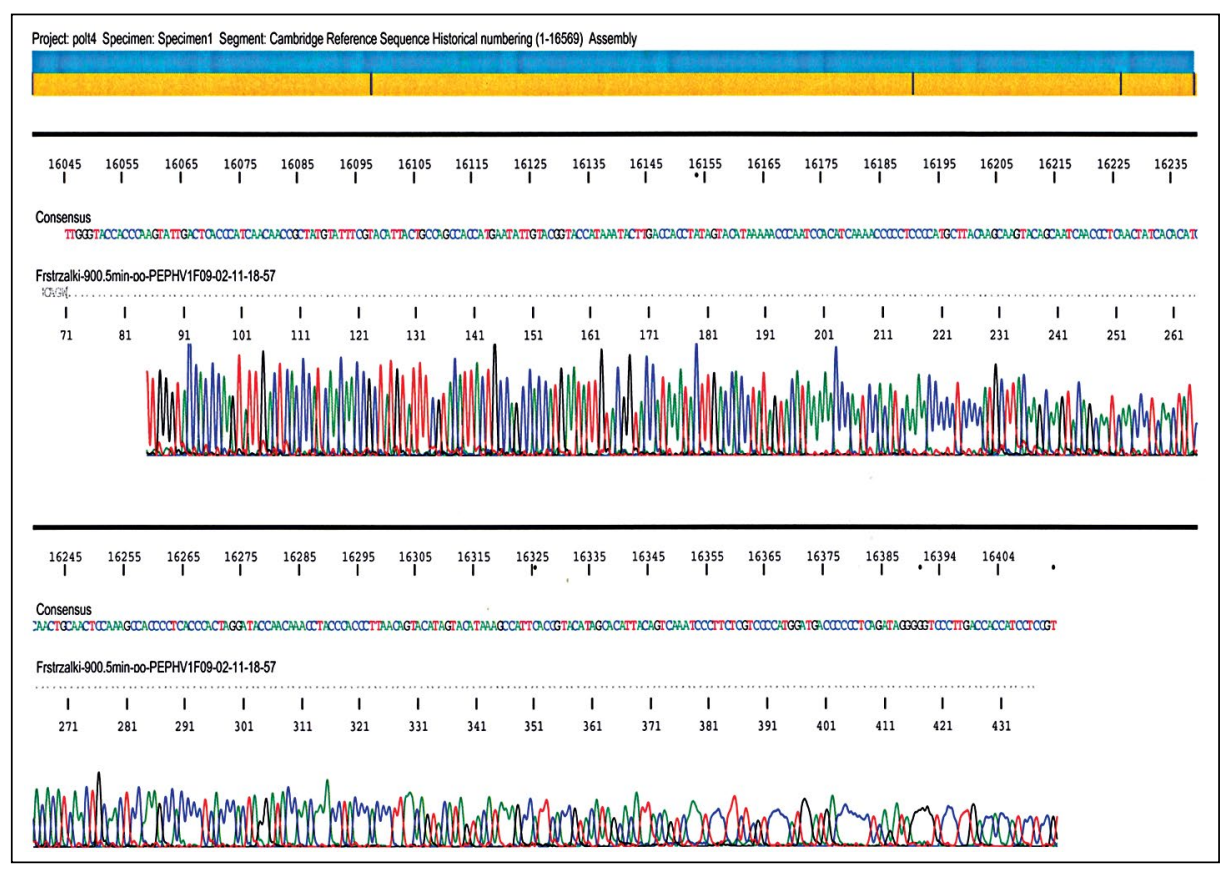

Figure 3. The profile of the HVI mtDNA region obtained for a fibula fragment exposed to $900^{\circ} \mathrm{C}$ for 5 min and reactivated using the PEP technique. The profile was obtained as described in Material and methods

fragments of heart, liver and thigh muscle exposed to temperatures up to $900^{\circ} \mathrm{C}$ yielded complete and reliable profiles for all the tested systems (SGMPlus, MiniFiler and mtDNA). However, at $1000^{\circ} \mathrm{C}$ no DNA profiles were obtained for any of the three systems tested (Table 1).

\section{Combustion of soft tissues for 10 minutes}

As compared with the combustion of the analyzed tissues at various temperatures for 5 minutes, extending the high temperature exposure to 10 minutes reduced the ability of successful SGMPlus, MiniFiler and mtDNA analysis at $300^{\circ} \mathrm{C}$ (Table 2).

Complete and reliable SGMPlus, MiniFiler and mtDNA profiles of thin tissue fragments $(0.5 \mathrm{~cm}-$ -thick) were obtained after treatment for 10 minutes at $100-300^{\circ} \mathrm{C}$ (heterozygote ratios $\geq 60 \%$ and lack of allele drop-out and loci drop-out and additional peaks (Table 2).

After the treatment at higher temperatures $\left(500-1000^{\circ} \mathrm{C}\right)$, the adipose tissue did not yield amplification in any of the tested systems (SGMPlus, MiniFiler and mtDNA) (Table 2). For the other soft tissue samples, i.e. fragments of heart, liver and thigh muscle, exposed to $500^{\circ} \mathrm{C}$, we observed incomplete SGMPlus profiles (Supplementary Figure 10). Full MiniFiler and mtDNA profiles were obtained for $0.5 \mathrm{~cm}$-thick fragments of heart, liver, and thigh muscle exposed to temperatures from $100^{\circ} \mathrm{C}$ to $500^{\circ} \mathrm{C}$ (Supplementary Figure 11).
Complete and reliable profiles of all the analyzed systems (SGMPlus, MiniFiler and mtDNA) were obtained from the $2 \mathrm{~cm}$-thick fragments of heart, liver and thigh muscle (except for adipose tissue) exposed to temperatures from $100^{\circ} \mathrm{C}$ to $500^{\circ} \mathrm{C}$ (Table 2). The treatment at higher temperatures $\left(800-1000^{\circ} \mathrm{C}\right)$ resulted in the lack of DNA amplification in all the analyzed systems (SGMPlus, MiniFiler and mtDNA) (Table 2).

Figures 4 and 5 show the effects of the temperature, combustion time and thickness of the thigh muscle sample on the SGMPlus and MiniFiler signals, respectively. To compare the effects of several factors on the signals of the DNA profiles, we tried to maximally stabilize several factors, such as the DNA input in the PCR reaction (1 ng if possible) and the conditions of injection and electrophoresis (injection time $5 \mathrm{sec}$, injection voltage $1.2 \mathrm{kV}$, EP voltage $15 \mathrm{kV}$, oven temp. $60^{\circ} \mathrm{C}$ ). Particular points of the curves show the sum of the areas of the peaks for all the alleles in the profile, which exceeded the height of $100 \mathrm{RFU}$ (relative fluorescence units). As expected, it was observed that prolonged exposure to high temperature increased degradation of DNA in thigh muscle tissues. The graphs (Figures 4 and 5) show that an increase in the thickness of a tissue sample and a reduction of the time of exposure to high temperature caused less DNA degradation than reduction of the thickness and prolongation of the exposure. The clear effect of DNA degradation was visible from $100^{\circ} \mathrm{C}$ (Figures 4 and 5), 


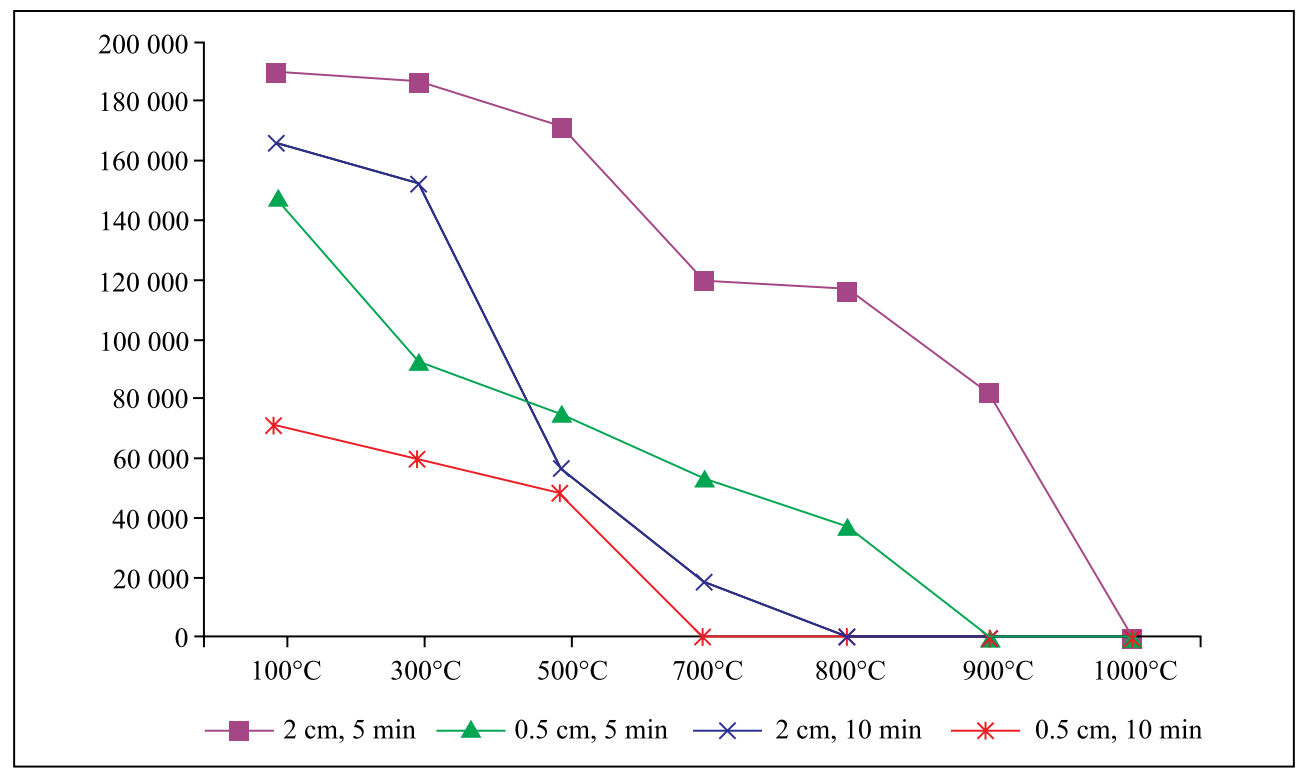

Figure 4. The effects of temperature, time of exposure and thickness of the thigh muscle sample on the SGMPlus amplification signal. $\mathrm{X}$ axis - the combustion temperature; $\mathrm{Y}$ axis - the sum of allele peak areas

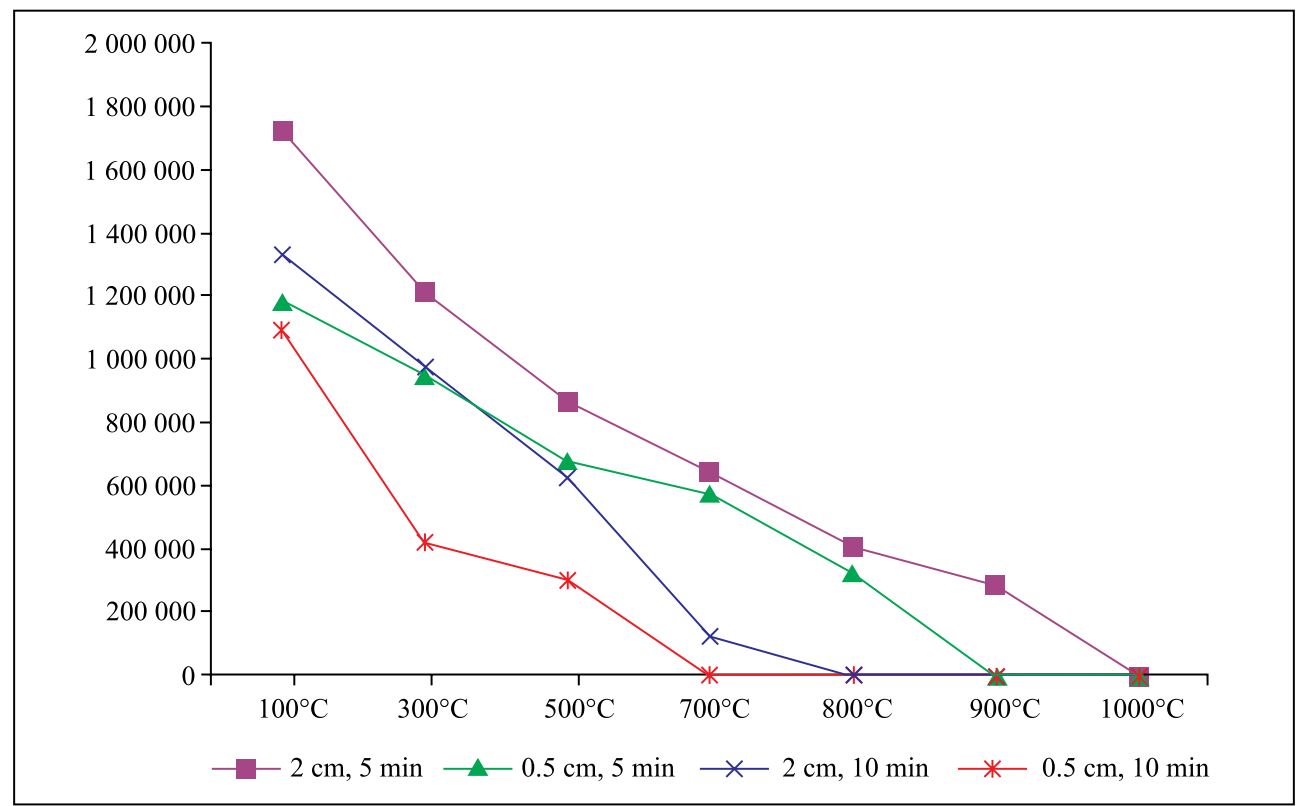

Figure 5. The effects of temperature, time of exposure and thickness of the femoral muscle tissue sample on the Minifiler amplification signal. X-axis - the combustion temperature; Y-axis - the sum of allele peak areas

while the highest degradation effect was present for the $0.5 \mathrm{~cm}$-thick fragments.

The analysis of the curves for the $2 \mathrm{~cm}$-thick samples treated for 10 minutes and the $0.5 \mathrm{~cm}$-thick samples treated for 5 minutes shows, that in the given conditions, the time of the high temperature exposure has higher effect on DNA degradation than the thickness of the tissue fragment (Figures 4 and 5). For
$0.5 \mathrm{~cm}$-thick fragments of thigh muscle exposed to high temperatures for 5 and 10 minutes, we observed lower $(0.5 \mathrm{~cm}, 5 \mathrm{~min})$ or significantly lower $(0.5 \mathrm{~cm}$, $10 \mathrm{~min}$ ) amplification signals (RFU) for SGMPlus loci, compared with $2 \mathrm{~cm}$-thick fragments of thigh muscle exposed to the same temperature for 5 and 10 minutes (Figure 4). DNA of a $2 \mathrm{~cm}$-thick muscle fragment exposed to high temperature for 10 minutes undergoes 
faster degradation at $500^{\circ} \mathrm{C}$ than DNA present in the $0.5 \mathrm{~cm}$-thick tissue fragment and exposed to a high temperature for $5 \mathrm{~min}$. A similar phenomenon was observed for the MiniFiler loci (Figure 5). These findings suggest a practical hint for the collection of body parts exposed to high temperatures (e.g. fires after explosions resulting in bodies' fragmentation). In such cases, for identification purposes by DNA analysis the fragments of highest weight (thickness) should be preferred.

\section{Discussion}

In cases of crimes and random events (arsons, fires, air catastrophes) and particularly in terrorist attacks, high temperatures cause severe thermal degradation of biological material [1-6]. The main aim of this study was to investigate the availability of DNA isolated from various human tissue samples (thigh skeletal muscle, liver, cardiac muscle, adipose tissue with hypodermis fragments, hair, nails and fibula fragments) exposed to high temperatures of $100-1000^{\circ} \mathrm{C}$ for 5 and 10 minutes.

Our findings show that hair and nails are completely unsuitable for identification purposes in temperatures higher than $100^{\circ} \mathrm{C}$. Hair and nails are products of epidermis and are composed primarily of keratin, which is insoluble in water. It appears that their small water content plays an essential role in unsuccessful typing of these biological samples. There are no published data concerning the influence of high temperature on DNA contained in hair and nails.

We showed that mtDNA present in teeth is more stable in high temperature than nuclear DNA. In our opinion, the higher sensitivity of mtDNA method compared with STR and miniSTR profiling is caused by the high copy number of mtDNA in cells, and thus a greater probability of correct identification.

Remualdo et al. [34] studied the possibility of amplification of DNA isolated from teeth subjected to $200^{\circ} \mathrm{C}$, $400^{\circ} \mathrm{C}, 500^{\circ} \mathrm{C}$ and $600^{\circ} \mathrm{C}$ for 60 minutes. They found that amplification of the autosomal loci of $50 \%$ of the samples exposed to $200^{\circ} \mathrm{C}$ and $400^{\circ} \mathrm{C}$ was successful (they applied organic method of DNA isolation), whereas after exposure to higher temperatures $\left(500^{\circ} \mathrm{C}\right.$ and $600^{\circ} \mathrm{C}$ ), only $\mathrm{mtDNA}$ could be successfully amplified [34]. In the experiments of Dobberstein et al. [35], human teeth were subjected to accelerated thermal degradation at $90^{\circ} \mathrm{C}$. They found that amplification of nuclear DNA (164 bp) and mtDNA (260 bp) was possible with samples exposed to this temperature for up to 48 hours. Repeatable and reliable amplification of STR sequences was possible for samples exposed at $90^{\circ} \mathrm{C}$ for up to 16 hours. The most rapid thermal deg- radation of DNA was observed after the first six hours of exposure [35]. Tsuchimochi et al. [36] subjected teeth to temperatures of $100^{\circ} \mathrm{C}, 200^{\circ} \mathrm{C}, 300^{\circ} \mathrm{C}, 400^{\circ} \mathrm{C}$ and $500^{\circ} \mathrm{C}$ for 2 minutes and showed that amelogenin locus and Y chromosome sequences could be identified only up to $300^{\circ} \mathrm{C}$ treatment. Thus, both these observations as well as our findings, demonstrate low thermal stability of the DNA in human teeth.

DNA contained in fibula fragments is more stable in high temperature in comparison with teeth DNA, as showed in our paper. Cattaneo et al. [37] exposed human bones (just after death and exhumed) to $800^{\circ} \mathrm{C}$ to $1200^{\circ} \mathrm{C}$ for 20 minutes. According to the authors, these conditions are equivalent to the temperatures occurring during house fires or when a car burns. It was not possible to obtain an mtDNA profile for the aforementioned conditions in any of the cases. These results are consistent with those obtained in our study. As demonstrated in this publication, a new strategy enabling identification of highly thermally degraded DNA contained in bones may be application of PEP technique.

There is lack of published data on the influence of temperature, duration of combustion and thickness of the soft tissue fragments on DNA stability. Our work provides important new findings showing that high temperature degrades DNA in hard tissues such as teeth and bones to a greater degree than in soft tissues. The results obtained for the analyzed soft tissues (fragments of heart, liver and thigh muscle) suggest that significantly higher water content could be one of the reasons for the greater stability of DNA in soft tissues compared with that in hard tissues and hair and nails. The high heat capacity of water might protect the DNA contained in these tissues.

We have also demonstrated that higher thickness of a tissue sample and a reduction of the time of its exposure to high temperature caused less DNA degradation than reduction of the thickness and prolongation of the exposure. The obtained much higher amplification signals (RFU) of the MiniFiler than for the SGMPlus profiles indicate that short DNA fragments are preserved much longer in high temperature and therefore offer more opportunities to achieve positive DNA identification. It appears that in the genetic analysis of victims of high temperature injuries, soft tissues and tissues located deeper in the body yields a better probability for identification than hard tissues, because of the demonstrated thickness effect on DNA preservation. Therefore, in the cases of fragments of human remains exposed to high temperature, samples of soft tissues of the highest weight (thickness) should be collected for the genetic analysis, which gives the best chance of successful identification. 


\section{Conclusions}

The performed experiments have clearly shown that DNA stability in tissues subjected to high temperatures depends on tissue type and thickness and time of exposure being the major ones. For the identification aims targeting shorter amplicons, thicker tissue sample, and application of mtDNA profiling are the recommended techniques. Nails and hair are not suitable for identification purposes since they are highly prone to complete thermal degradation at $100^{\circ} \mathrm{C}$. High temperatures degrade DNA in hard tissues such as teeth and bones to a greater degree than in soft tissues. In cases of high temperature exposure on fragments of human remains, the thickest parts of soft tissues should be collected for identification purposes. In cases of negative mtDNA typing application of the WGA technique could provide the expected results for highly degraded DNA templates. Tissues exposure to temperatures higher than $900^{\circ} \mathrm{C}$ does not allow obtaining DNA profiles in any of the analyzed loci for any tissue.

\section{References}

1. Sudoyo H, Widodo PT, Suryadi $\mathrm{H}$ et al. DNA analysis in perpetrator identification of terrorism-related disaster: Suicide bombing of the Australian Embassy in Jakarta 2004. Forensic Sci Int Genet. 2008;2:231-237. doi: 10.1016/j.fsigen.2007.12.007.

2. Foran DR, Gehring ME, Stallworth SE. The recovery and analysis of mitochondrial DNA from exploded pipe bombs. J Forensic Sci. 2009;54:90-94. doi: 10.1111/j. 1556-4029.2008.00901.x.

3. Alonso A, Martín P, Albarrán C et al. Challenges of DNA profiling in mass disaster investigations. CMJ. 2005;46:540-548. PMID: 16100756.

4. Holland MM, Cave ChA, Holland ChA et al. Development of a quality, high throughput DNA analysis procedure for skeletal samples to assist with the identification of victims from the World Trade Center attacks. CMJ. 2003;44:264-272. PMID: 12808717.

5. Budimlija ZM, Prinz MK, Zelson-Mundorff A et al. World Trade Center Human Identification Project: experiences with individual body identification cases. CMJ. 2003;44:259-263. PMID: 12808716

6. Biesecker LG, Bailey-Wilson JE, Ballantyne J et al. DNA identifications after the 9/11 World Trade Center attack. Science. 2005;18:1122-1123. doi: 10.1126/science.1116608.

7. Petricevic S, Whitaker J, Buckleton J et al. Validation and development of interpretation guidelines for low copy number (LCN) DNA profiling in New Zealand using AmpFlSTR SGM Plus ${ }^{\mathrm{TM}}$ multiplex. Forensic Sci Int Genet. 2010;4:305-310. doi: 10.1016/j.fsigen.2009.11.003.

8. Mameli A, Piras G, Delogu G. The successful recovery of low copy number and degraded DNA from bones exposed to seawater suitable for generating a DNA STR profile. J Forensic Sci. 2014;59:470-473. doi: 10.1111/1556-4029.12323.

9. Grubwieser P, Muhlamann R, Berger B et al. A new "miniSTR-multiplex" displaying reduced amplicon lengths for the analysis of degraded DNA. Int J Legal Med. 2006;120:115-120. doi: 10.1007/s00414-005-0013-6.
10. Opel KL, Chung DT, Drabek J et al. The application of miniplex primer set in the analysis of degraded DNA from skeletal remains. J Forensic Sci. 2006;51:351-356. doi: 10.1111/j.15564029.2006.00077.x.

11. Graw M, Weisser HJ, Lutz S. DNA typing of human remains found in damp environments. Forensic Sci Int. 2000;113:91-95. PMID: 10978607.

12. Ziętkiewicz E, Witt M, Daca P et al. Current genetic methodologies in the identification of disaster victims and in forensic analysis. J Appl Genetics. 2012;53:41-60. doi: 10.1007/s13353-011-0068-7.

13. Milos A, Selmanović A, Smajlović L et al. Success rates of Nuclear Short Tandem Repeat Typing from Different Skeletal Elements. Croat Med J. 2007;48:486-493.

14. Courts C, Sauer E, Hofmann Y et al. Assessment of STR Typing Success Rate in Soft Tissues from Putrefied Bodies Based on a Quantitative Grading System for Putrefaction. JForensic Sci. 2015;60:1016-1021. doi: 10.1111/1556-4029.12746.

15. Mulero JJ, Chang ChW, Lagacė RE et al. Development and Validation of the AmpFISTR MiniFiler PCR Amplification Kit: A MiniSTR Multiplex for the Analysis of Degraded and/ /or PCR Inhibited DNA.J Forensic Sci. 2008;53:838-851. doi: 10.1111/j.1556-4029.2008.00760.x.

16. Coble MD, Loreille OM, Wadhams MJ et al. Mystery solved: the identification of the two missing Romanov children using DNA analysis. PLoS One. 2009;4:e4838. doi: 10.1371/journal. pone. 0004838 .

17. Parson W, Brandstatter A, Alonso A et al. The EDNAP mitochondrial DNA population database (EMPOP)collaborative exercises: organisation, results and perspectives. Forensic Sci Int. 2004;139:215-226. PMID: 15040920.

18. Parson W, Bandelt HJ. Extended guidelines for mtDNA typing of population data in Forensic Science. Forensic Sci Int Genet. 2007;1:13-19. doi: 10.1016/j.fsigen.2006.11.003.

19. Stephen CY, Sze-wah Ch, Li Ch et al. Forensic DNA typing strategy of degraded DNA on discarded cigarette ends using the AmpFlSTR ${ }^{\circledR}$ Identifiler $^{\circledR}$, Plus and MiniFiler ${ }^{\mathrm{TM}}$ PCR Amplification Kits. Sci Just. 2004;54:313-315. doi: 10.1016/j. scijus.2014.04.007.

20. Applied Biosystems. AmpFlSTR SGM ${ }^{\mathrm{TM}}$ PCR amplification kit user guide.

21. Applied Biosystems. AmpFlSTR MiniFiler ${ }^{\mathrm{TM}}$ PCR amplification kit user guide.

22. Luce C, Montpetit S, Gangitano D et al. Validation of the AmpFlSTR MiniFiler PCR Amplification Kit for Use in Forensic casework. J Forensic Sci. 2009;54:1046-1054. doi: 10.1111/j.1556-4029.2009.01099.x.

23. Bender K, Schneider PM, Rittner C. Application of mtDNA sequence analysis in forensic casework for identification of human remains. Forensic Sci Int. 2000;113:103-107. doi: 10.1016/S0379-0738(00)00223-1.

24. Ballantyne KN, Oorschot RA, Mitchell RJ. Increasing amplification success of forensic DNA samples using multiple displacement amplification. Sci Med Pathol. 2007;3:182-187. doi: 10.1007/s12024-007-0017-2.

25. Dean FB, Hosono S, Fang L et al. Comprehensive human genome amplification using multiple displacement amplification. PNAS. 2002;99:5261-5266. doi: 10.1073/pnas.082089499.

26. Zhang L, Cui X, Schmitt K et al. Whole genome amplification from a single cell: Implications for genetic analysis. Proc Natl Acad Sci. 1992;89:5847-5851. PMID: 1631067.

27. Maciejewska A, Jakubowska J, Pawłowski R. Whole genome amplification of degraded and nondegraded DNA for forensic purposes. Int J Legal Med. 2013;127:309-319. doi: 10.1007/ s00414-012-0764-9. 
28. Nara A, Harihara S, Iwadate $\mathrm{K}$ et al. Sequence analysis for HVI region of mitochondrial DNA using WGA (Whole Genome Amplification) method. Leg Med. 2009;11:115-118. doi: 10.1016/j.legalmed.2009.01.114.

29. Jakubowska J, Maciejewska A, Pawłowski R. Comparison of three methods of DNA extraction from human bones with different degrees of degradation. Int J Leg Med. 2012;126:173-178. doi: 10.1007/s00414-011-0590-5.

30. Allouche M, Hamdoum M, Mangin P et al. Genetic identification of decomposed cadavers using nails as DNA source. Forensic Sci Int Genet. 2008;3:46-49. doi: 10.1016/j.fsigen.2008.07.008.

31. Jehaes E, Gilissen A, Cassiman JJ et al. Evaluation of a decontamination protocol for hair shafts before mtDNA sequencing. Forensic Sci Int. 1998;94:65-67. doi: 10.1016/ S0379-0738(98)00052-8.

32. Comey CT, Koons BW, Presley KW et al. DNA Extraction Strategies for Amplified Fragment Length Polymorphism Analysis. J Forensic Sci. 1994;39:1254-1269.

33. Pawłowski R, Maciejewska A. Forensic validation of multiplex containing nine STRs - population genetics in Northern Poland. Int J Legal Med. 2000;114:45-49.
34. Remualdo VR. Avaliação de três métodos de extração de DNA de dentes humanos submetidos ao calor [dissertação]. São Paulo (SP): Faculdade de Odontologia, Universidade de São Paulo, 2004.

35. Dobberstein RC, Huppertz J, Wurmb-Schwark N et al. Degradation of biomolecules in artificially and naturally aged teeth: Implications for age estimation based on aspartic acid racemization and DNA analysis. Forensic Sci Int. 2008;179:181-191. doi: 10.1016/j.forsciint.2008.05.017.

36. Tsuchimochi T, Iwasa M, Maeno $\mathrm{Y}$ et al. Chelating resin-based extraction of DNA from dental pulp and sex determination from incinerated teeth with Y-chromosomal alphoid repeat and short tandem repeats. Am J Forensic Med Pathol. 2002;23:268-271. doi: 10.1097/00000433-20020900000013.

37. Cattaneo C, DiMartino S, Scali S et al. Determining the human origin of fragments of burnt bone: a comparative study of histological, immunological and DNA techniques. Forensic Sci Int. 1999;102:181-191. PMID: 10464934.

Submitted: 1 September, 2015 Accepted after reviews: 26 October, 2015 Available as AoP: 29 October, 2015 